\title{
ANALISIS KEMAMPUAN DAN KESULITAN DALAM MENYELESAIKAN SOAL BERPIKIR LOGIS MATEMATIK SISWA SMP DENGAN PENGGUNAAN GEOGEBRA
}

\author{
Gagan Aditya Fauzan ${ }^{1}$, Selvia Agina ${ }^{2}$, Wahyu Setiawan ${ }^{3}$ \\ 1,2,3 IKIP Siliwangi Cimahi, Jl. Terusan Jenderal Sudirman, Cimahi Tengah, Kota Cimahi, Jawa Barat \\ gaganaditya197@gmail.com
}

\begin{abstract}
The purpose of this study is to describe the difficulties of students in solving problems of mathematical logical thinking ability, and to compare students 'ability to work on students' mathematical logical thinking problems between classes with the use of GeoGebra software and classes without the use of GeoGebra software in learning. This type of research is a qualitative research. This research was conducted at SMPN 2 Kersamanah. With class VIII D as an experimental class and class VIII B as a control class with a total of 28 students. This study uses a valid and reliable instrument with a total of 5 questions. Overall the experimental class gained a percentage of logical thinking skills of $76.4 \%$ with a good classification and an experimental class of $56.8 \%$ with a sufficient classification. In the experimental class students only had difficulty with question number 4 . Whereas the control class had difficulty with questions number 2.4 , and 5 . The author also found the difficulty of students in both the experimental class and the control class in working on the question form in the exact form on question number 4 with elaboration facts in the form of stories that must be translated into tangent form circles. The results of the analysis and description show that the use of GeoGebra software in learning has a good impact on the mathematical logical thinking ability of junior high school students.
\end{abstract}

Keywords: Geogebra Software, Students' Mathematical Logical Thinking Ability, Middle School Students

\begin{abstract}
Abstrak
Tujuan penelitian ini yakni untuk menjabarkan kesulitan siswa dalam menyelesaikan soal kemampuan berpikir logis matematik, serta membandingkan kemampuan siswa dalam mengerjakan soal berpikir logis matematik siswa antara kelas dengan penggunaan software GeoGebra dan kelas tanpa penggunaan software GeoGebra dalam pembelajaran. Jenis penelitian ini merupakan penelitian kualitatif. Penelitian ini dilaksanakan di SMPN 2 Kersamanah. Dengan kelas VIII D sebagai kelas eksperimen dan kelas VIII B sebagai kelas kontrol dengan jumlah 28 siswa. Penelitian ini menggunakan instrumen yang valid dan reliabel dengan jumlah 5 soal. Secara keseluruhan kelas eksperimen memperoleh persentase kemampuan berpikir logis sebesar 76,4\% dengan klasifikasi baik dan kelas eksperimen yakni 56,8\% dengan klasifikasi cukup. Pada kelas eksperimen siswa hanya mengalami kesulitan pada soal nomor 4. Sedangkan kelas kontrol mengalami kesulitan pada soal nomor 2,4, dan 5. Penulis juga menemukan kesulitan siswa baik kelas eksperimen dan kelas kontrol dalam mengerjakan soal berbentuk cerita tepatnya pada soal nomor 4 dengan penjabaran fakta berupa cerita yang harus dijabarkan kedalam bentuk persamaan garis singgung lingkaran. Hasil analisis dan deskripsi menunjukan bahwa penggunaan software GeoGebra dalam pembelajaran memberikan dampak baik terhadap kemampuan berpikir logis matematik siswa SMP.
\end{abstract}

Kata Kunci: Software Geogebra, Kemampuan Berpikir Logis Matematik Siswa, Siswa SMP

\section{PENDAHULUAN}

Matematika merupakan ilmu dasar yang mempunyai peranan penting untuk menguasai ilmu pengetahuan dan teknologi. Hal ini sejalan dengan Ruseffendi (Yanti et. al, 2019) yang menyatakan bahwa matematika merupakan ratu ilmu atau induknya ilmu pengetahuan yang lain. Tujuan dari pembelajaran matematika adalah untuk menciptakan insan akademik yang siap menghadapi berbagai perembangan zaman. Hal ini sejalan dengan pernyataan Puskur (Usdyana et. al, 2009) bahwa tujuan pembelajaran matematika di jenjang pendidikan dasar dan pendidikan menengah adalah untuk mempersiapkan siswa agar sanggup menghadapi perubahan keadaan di dalam kehidupan dan di dunia yang selalu berkembang, melalui latihan bertindak atas dasar pemikiran secara logis, rasional, kritis, cermat, jujur, efisien, dan efektif. 
Menurut Setiawan (2015) untuk membentuk siswa yang cakap dibidang pendidikan dan teknologi siswa dituntut untuk memiliki berbagai macam kemampuan. Salah satu kemampuan yang sangat penting dalam dunia pendidikan umumnya dan dalam pembelajaran matematika khususnya yakni kemampuan berpikir logis. Kemampuan berpikir logis sudah teruji sebagai kemampuan yang sangat penting untuk menunjang kemampuan matematika dan sains. Hal ini diperkuat dengan penelitian yang dilakukan oleh Puspitasari (2019) yang menunjukkan bahwa kemampuan berpikir logis dapat meningkatkan hasil belajar siswa terhadap konsep matematika siswa SMP.

Kemampuan berpikir logis diperlukan oleh siswa baik pada saat pembelajaran dalam kelas, berdiskusi kelompok, memecahkan permasalahan tentunya memerlukan kemampuan untuk menghubungkan sesuatu yang ada dalam sekitar yang dapat dipahami oleh nalar, sehingga dapat di implementasikan sebagai logika untuk menyelesaikan suatu permasalahan. Hal ini sejalan dengan yang dikemukakan oleh Hadi (2004) yang menyatakan berpikir logis merupakan cara berpikir yang runtut masuk akal, dan berdasarkan fakta-fakta objektif tertentu. Selain harus dimiliki oleh siswa, menurut Erihadiana (Octaria, 2017) bahwa calon guru harus menguasai kemampuan berpikir sistematis, terutama berpikir logis dan ilmiah. Adapun indikator penalaran logis matematik dirangkum oleh Sumarmo (Hidayat, 2013) antara lain sebagai berikut: (a) menarik kesimpulan analogi, generalisasi, dan menyusun konjektur; (b) menarik kesimpulan logis berdasarkan aturan inferensi, memeriksa validitas argumen, dan menyusun argumen yang valid; (c) menyusun pembuktian langsung, tak langsung, dan dengan induksi matematik. Kemudian ia merinci berpikir logis matematik ke dalam komponen, penalaran logis, mengontrol variabel, penalaran proporsional, penalaran probabilistik, penalaran korelasional, dan penalaran kombinatorik. Analisis tersebut melukiskan bahwa berpikir logis memiliki cakupan yang lebih luas dari pada penalaran logis.

Selain meningkatkan kemampuan siswa, guru juga dituntut untuk memiliki inovasi-inovasi dalam kegiatan pembelajaran. Dalam kurikulum 2013 guru dituntut untuk mengintegrasikan antara pembelajaran dan teknologi. Dimana TIK yang sebelumnya mata pelajaran berubah menjadi media pembelajaran bagi setiap mata pelajaran di sekolah tak terkecuali matematika. Dewasa ini dalam dunia perkuliahan mulai dikenal aplikasi GeoGebra namun dalam pengamatan penulis sebagian besar guru di sekolah belum mengenal aplikasi GeoGebra. GeoGebra adalah program komputer (software) untuk membelajarkan matematika khsusunya geometri dan aljabar (Hohenwarter, 2008). Menurut Hohenwarter (2008) program GeoGebra sangat bermanfaat bagi guru maupun siswa. Tidak sebagaimana pada penggunaan software komersial yang biasanya hanya bisa dimanfaatkan di sekolah, GeoGebra dapat diinstal pada komputer pribadi dan dimanfaatkan kapan dan di manapun oleh siswa. Menurut Hohenwarter (2008), GeoGebra sangat bermanfaat sebagai media pembelajaran matematika dengan beragam aktivitas sebagai media demonstrasi dan visualisasi, sebagai alat bantu konstruksi, dan memvisualisasikan konstruksi konsep matematika tertentu, dan alat bantu proses penemuan.

Berdasarkan pemaparan mengenai pentingnya kemampuan berpikir logis matematik serta peranan alplikasi GeoGebra dalam pembelajaran matematika. Penulis tergerak untuk menganalisis 
kemampuan dan kesulitan siswa dalam menyelesaikan soal kemampuan berpikir logis matematik siswa di SMPN 2 Kersamanah baik yang menggunakan aplikasi GeoGebra maupun tanpa menggunakan aplikasi GeoGebra.

\section{METODE}

Penelitian ini merupakan penelitian kualitatif. Menurut Arifin (Zulfah, 2019) penelitian kualitatif yakni penelitian yang digunakan untuk menggambarkan, menjelaskan, dan menjawab berbagai persoalan mengenai fenomena dan peristiwa yang terjadi saat ini. Penelitian kualitatif digunakan dikarenakan penelitian ini bertujuan untuk menganalisis kemampuan serta kesulitan siswa dalam menyelesaikan soal kemampuan beripikir logis matematik baik kelas eksperimen maupun kelas kontrol. Populasi penelitian ini yakni siswa kelas VIII SMPN 2 Kersamanah Kabupaten Garut periode 2018/2019. Sedangkan sampel penelitian adalah kelas VIII D sebagai kelas eksperimen yaitu kelas dengan penggunaan GeoGebra dalam pembelajaran dan kelas VIII B sebagai kelas kontrol yaitu kelas tanpa penggunaan GeoGebra dalam pembelajaran dengan jumlah siswa masing-masing 28 siswa. Dasar pemilihan sampel tersebut adalah peneliti memilih dua kelas yang memiliki kemampuan matematik yang sama ditinjau dari hasil ulangan harian kedua kelas tersebut dan usulan dari guru mata pelajaran matematika.

Teknik pengumpulan data dalam penelitian ini adalah metode tes. Instrumen penelitian yakni terdiri dari 5 butir soal kemampuan berpikir logis matematik pada materi lingkaran. Kelima soal tersebut sudah teruji dan dapat digunakan karena telah dilakukan uji validitas, realibilitas, daya pembeda, dan tingkat kesukaran yang memadai. Sedangkan teknik analisis data dalam penelitian ini adalah analisis deskriptif, yaitu menganalisis data dengan cara mendeskripsikan atau menggambarkan data yang sudah terkumpul (Zulfah, 2017). Data yang dihasilkan dipersentasekan terhadap SMI (skor maksimal ideal) sehingga data tersebut dapat digunakan untuk mengukur kemampuan berpikir logis matematik siswa. Data dikategorikan dengan batasan yang diungkapkan oleh Arikunto (2008) yang tercantum pada tabel 1 berikut:

\section{Tabel 1.}

\section{Kriteria Data}

\begin{tabular}{cc}
\hline Skor Persentase & Interpretasi \\
\hline $81 \%-100 \%$ & Sangat Baik \\
$61 \%-80 \%$ & Baik \\
$41 \%-60 \%$ & Cukup \\
$21 \%-40 \%$ & Rendah \\
$0 \%-20 \%$ & Sangat Rendah \\
\hline
\end{tabular}

Sedangkan untuk mengetahui siswa kesulitan atau tidaknya dalam mengisi soal kemampuan berpikir logis matematik menurut Putra (2017) belajar dinilai berhasil jika siswa dapat menyelesaikan paket tes dengan rata-rata $60 \%$ ke atas. Berdasarkan pernyataan tersebut maka kriteria keesulitan siswa dalam menyelesaikan soal kemampuan berpikir logis matematik antara lain sebagai berikut: 
1. Jika persentasi skor terhadap $\mathrm{SMI} \geq 60 \%$ berarti siswa tidak mengalami kesulitan dalam menyelesaikan soal-soal kemampuan berpikir logis matematis.

2. Jika persentasi skor terhadap SMI $<60 \%$ berarti siswa mengalami kesulitan dalam menyelesaikan soal-soal kemampuan berpikir logis matematis.

\section{HASIL}

Berikut ini adalah hasil data persentase skor terhadap SMI baik kelas eksperimen maupun kelas kontrol.

Tabel 2.

Persentase Skor Terhadap SMI Kemampuan Berpikir Logis Matematis Kelas Eksperimen

\begin{tabular}{clc}
\hline $\begin{array}{c}\text { Nomor } \\
\text { Soal }\end{array}$ & \multicolumn{1}{c}{ Indikator } & \% \\
\hline $\mathbf{1}$ & menarik kesimpulan berdasarkan analogi & 98 \\
$\mathbf{2}$ & memeriksa atau menguji validitas argumen & 78 \\
$\mathbf{3}$ & menghubungkan antara fakta sebagai persamasalahan & 97 \\
& yang melibatkan pemikiran logis & 47 \\
$\mathbf{4}$ & menghubungkan antara fakta sebagai persamasalahan & 47 \\
& yang melibatkan pemikiran logis & 62 \\
\hline & membangun dan menetapkan asumsi & 76,4 \\
\hline
\end{tabular}

Tabel 3.

Persentase Skor Terhadap SMI Kemampuan Berpikir Logis Matematis Kelas Kontrol

\begin{tabular}{clc}
\hline $\begin{array}{c}\text { Nomor } \\
\text { Soal }\end{array}$ & \multicolumn{1}{c}{ Indikator } & \% \\
\hline $\mathbf{1}$ & menarik kesimpulan berdasarkan analogi & 74 \\
$\mathbf{2}$ & memeriksa atau menguji validitas argumen & 53 \\
$\mathbf{3}$ & menghubungkan antara fakta sebagai persamasalahan & 90 \\
& yang melibatkan pemikiran logis & 30 \\
$\mathbf{4}$ & menghubungkan antara fakta sebagai persamasalahan & 30 \\
& yang melibatkan pemikiran logis & 37 \\
\hline & membangun dan menetapkan asumsi & Total \\
\hline
\end{tabular}

Berdasarkan tabel 2 dan tabel 3 diatas maka diketahui secara keseluruhan kelas eksperimen mendapatkan persentase sebesar $76,4 \%$ dengan kriteria baik. Dan kelas kontrol mendapatkan persentase sebesar $56,8 \%$ dengan kriteria cukup.

Pada pembahasan akan dibahas mengenai analisis kesulitan baik kelas eksperimen maupun kelas kontrol.Berikut adalah pembahasan analisis kesulitan siswa baik kelas eksperimen maupun kelas kontrol 
Perhatikan kedua pernyataan dibawah!

Rangga akan membuat sebuah lingkaran dengan menggunakan benang. Saat dia membentuk lingkaran ternyata jari - jarinya $14 \mathrm{~cm}$ untuk membentuk panjang benang yang diperlukan dalam pembuatan lingkaran.

Bumi mengitari matahari dengan lintasan tertentu serta diketahui bahwa jarak atau jari - jari bumi dan matahari adalah sekitar 1.500.000 KM.

Dari kedua cerita diatas, analogi apa yang dapat anda simpulan?

\section{Gambar 1. Soal Nomor 1}

Pada soal nomor 1 dengan indikator menarik kesimpulan berdasarkan analogi, kelas eksperimen mendapat persentase sebesar 98\%. Hal ini menunjukan bahwa siswa pada kelas eksperimen tidak mengalami kesulitan dalam menyelesaikan soal nomor 1 dan berdampak besar terhadap peningkatan kemampuan berpikir logis matematis pada indikator menarik kesimpulan berdasarkan analogi. Berikut salah satu sampel jawaban siswa yang menjawab dengan benar soal nomor 1 pada indikator menarik kesimpulan berdasarkan analogi.

$$
\text { 1) Aari kedda ana logi dratas dapat discmpur kan mempahas tentang jari jari dan keliling lingkaran. }
$$

Gambar 2. Jawaban Siswa Nomor 1 Kelas Eksperimen

Sedangkan untuk kelas kontrol pada soal nomor 1 dengan indikator menarik kesimpulan berdasarkan analogi, mendapat persentase sebesar $74 \%$. Hal ini menunjukan bahwa siswa pada kelas kontrol tidak mengalami kesulitan dalam menyelesaikan soal nomor 1 dan berdampak cukup besar terhadap peningkatan kemampuan berpikir logis matematis pada indikator menarik kesimpulan berdasarkan analogi.

Menurut Ahmad daerah yang dibatasi garis EF merupakan tebereng, sedangkan menurut Jamil tembereng adalah daerah yang dibatasi oleh garis GH. Sedangkan menurut Alfa daerah yang dibatasi oleh garis EF, GH, IJ merupakan tembereng. Dari ketiga pernyataan diatas menurut anda manakah pernyataan yang tepat? Jelaskan alasanmu!

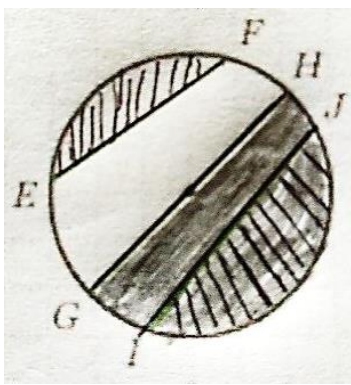

\section{Gambar 3. Soal Nomor 2}

Pada soal nomor 2 dengan indikator memeriksa atau menguji validitas argumen, mendapat persentase sebesar 78\%. Hal ini menunjukan bahwa siswa pada kelas eksperimen tidak mengalami kesulitan dalam menyelesaikan soal nomor 2 dan berdampak besar terhadap peningkatan kemampuan berpikir logis matematis pada indikator memeriksa atau menguji validitas argumen. Berikut salah satu sampel jawaban siswa yang menjawab dengan benar soal nomor 2 pada indikator memeriksa atau menguji validitas argumen. 


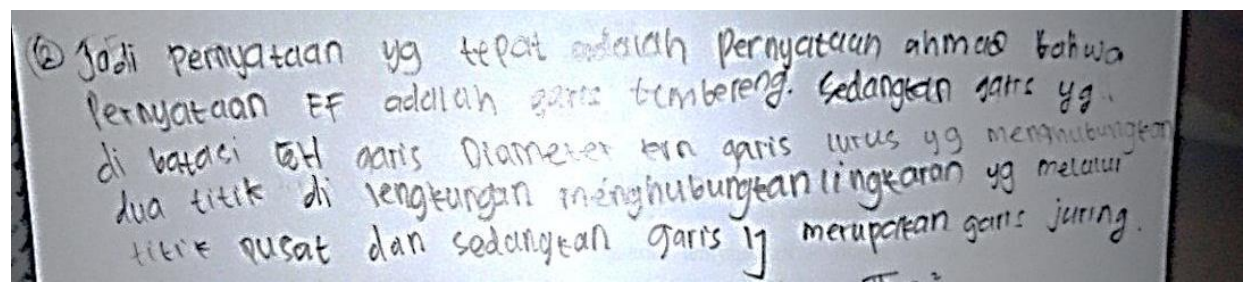

Gambar 4. Jawaban Siswa Nomor 2 Kelas Eksperimen

Sedangkan untuk kelas kontrol pada soal nomor 2 dengan indikator memeriksa atau menguji validitas argumen, mendapat persentase sebesar 53\%. Hal ini menunjukan bahwa siswa pada kelas kontrol mengalami kesulitan dalam menyelesaikan soal nomor 2. Berikut salah satu sampel jawaban siswa yang menjawab tidak tepat pada soal nomor 2 pada indikator memeriksa atau menguji validitas argumen.

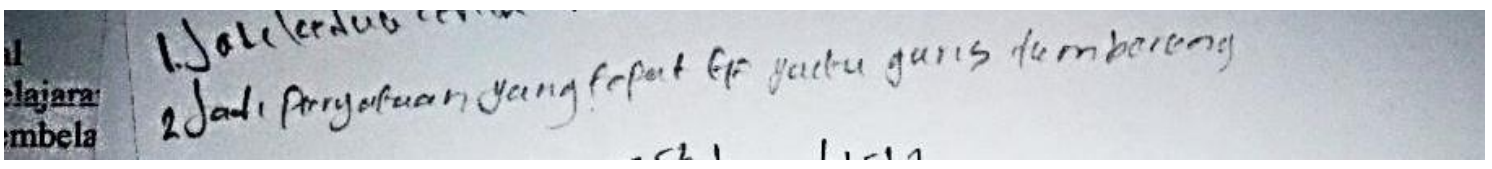

Gambar 5. Jawaban Siswa Nomor 2 Kelas Kontrol

Pada jawaban siswa diatas merupakan jawaban yang kurang tepat. Meskipun jawaban siswa mengarah pada jawaban yang benar, namun siswa tidak menentukan validitas argumen yang dipaparkan dalamsoal nomor 2. Karena selain jawaban yang tepat diperlukan juga untuk menentukan kebenaran suatu argumen yang diperkuat dengan pernyataan yang logis.

Seorang guru menugaskan siswa untuk menggambarkan luas setengah lingkaran dengan diameter $28 \mathrm{~cm}$. Andi menggambarkan luas setengah lingkaran, namun pendapat Bani bahwa menggambar luas setengah lingkaran berbeda dengan Andi seperti gambar dibawah:

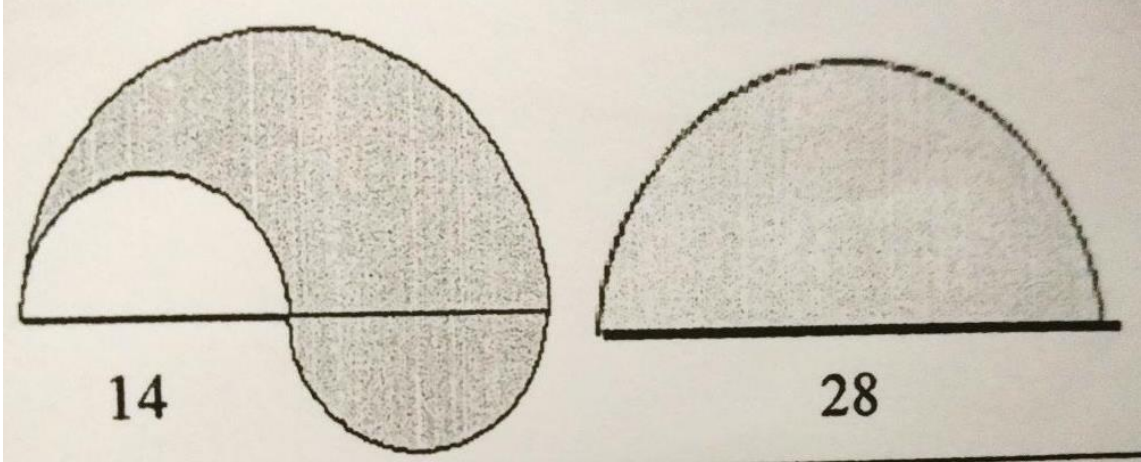

Dari informasi diatas, apakah pendapat Andi dan Bani berbeda mengenai luas setengah lingkaran? Jelaskan Alasanmu!

\section{Gambar 6. Soal Nomor 3}

Pada soal nomor 3 dengan indikator menghubungkan antara fakta sebagai persamasalahan yang melibatkan pemikiran logis, mendapat persentase sebesar 97\%. Hal ini menunjukan bahwa siswa pada kelas eksperimen tidak mengalami kesulitan dalam menyelesaikan soal nomor 3 dan berdampak besar terhadap peningkatan kemampuan berpikir logis matematis pada indikator menghubungkan antara 
fakta sebagai persamasalahan yang melibatkan pemikiran logis. Berikut salah satu sampel jawaban siswa yang menjawab dengan benar soal nomor 3 pada menghubungkan antara fakta sebagai persamasalahan yang melibatkan pemikiran logis

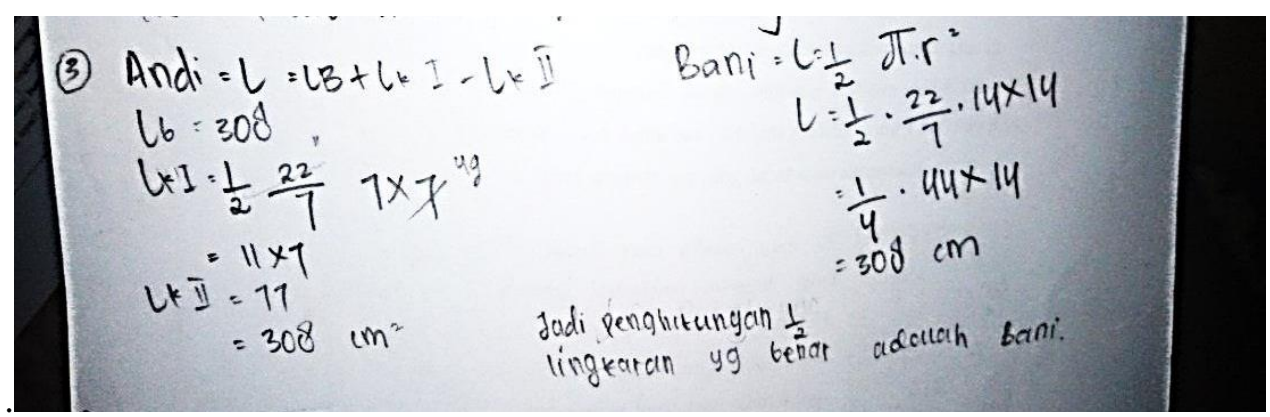

Gambar 7. Jawaban Siswa Nomor 3 Kelas Eksperimen

Senada dengan kelas eksperimen pada soal nomor 3 dengan indikator menghubungkan antara fakta sebagai persamasalahan yang melibatkan pemikiran logis, mendapat persentase sebesar $90 \%$. Hal ini menunjukan bahwa siswa pada kelas kontrol tidak mengalami kesulitan dalam menyelesaikan soal nomor 3 dan berdampak besar terhadap peningkatan kemampuan berpikir logis matematis pada indikator menghubungkan antara fakta sebagai persamasalahan yang melibatkan pemikiran logis pada soal nomor 3 ini.

Pada suatu hari Dek Lia mengendarai sebuah sepeda mini mengelilingi lapangan alun - alun
Kota Bandung. Namun pada saat berjalan rantai sepeda Dek Lia putus. Karena rantainya
beberapa sudah berkarat, sehingga rantai bagian atas yang menghubungkan antara gear
pertama dan gear kedua harus diganti. Diameter gear pertama sepeda Dek Lia adalah $25 \mathrm{~cm}$
dan diameter gear kedua adalah $10 \mathrm{~cm}$, dengan jarak antara keduanya (titik pusat) adalah 17
$\mathrm{~cm}$.
Dari informasi diatas, Angga mencoba membuat sepeda dengan menggunakan ukuran dua gear
yang berbeda yaitu $16 \mathrm{~cm}$ dan $10 \mathrm{~cm}$, dan memiliki panjang rantai atas yang sama dengan
ukuran rantai bagian atas sepeda Dek Lia.
Dapatkah Angga membuat sepeda berdasarkan cerita diatas? Jelaskan!

Gambar 8. Soal Nomor 4

Pada soal nomor 4 dengan indikator menghubungkan antara fakta sebagai permasalahan yang melibatkan pemikiran logis, mendapat persentase sebesar $47 \%$. Hal ini menunjukan bahwa siswa pada kelas eksperimen mengalami kesulitan dalam menyelesaikan soal nomor 4 dan berdampak tidak signifikan terhadap peningkatan kemampuan berpikir logis matematis pada indikator menghubungkan antara fakta sebagai persamasalahan yang melibatkan pemikiran logis pada soal no 4 ini. Berikut salah satu sampel jawaban tidak tepat siswa pada soal nomor 4 dengan indikator menghubungkan antara fakta sebagai persamasalahan yang melibatkan pemikiran logis. 


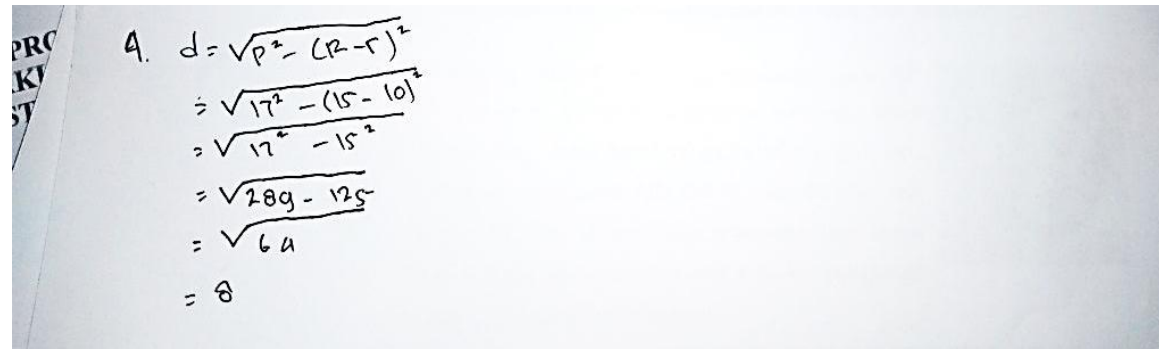

Gambar 9. Jawaban Siswa Nomor 4 Kelas Eksperimen

Pada jawaban siswa diatas jelas merupakan jawaban yang tidak tepat. Karena siswa tidak dapat menjabarkan fakta dalam permasalahan kedalam bentuk matematika dengan baik dan benar. Selain menjabarkan kedalam bentuk matematika siswa juga harus menarik sebuah argumen berdasarkan pemikiran logis berdasarkan permasalahan yang dipaparkan pada soal nomor 4 .

Sedangkan untuk kelas kontrol pada soal nomor 4 dengan indikator menghubungkan antara fakta sebagai persamasalahan yang melibatkan pemikiran logis, mendapat persentase sebesar $30 \%$. Hal ini menunjukan bahwa siswa pada kelas kontrol mengalami kesulitan dalam menyelesaikan soal nomor 4 dan berdampak tidak signifikan terhadap peningkatan kemampuan berpikir logis matematis pada indikator menghubungkan antara fakta sebagai persamasalahan yang melibatkan pemikiran logis pada soal no 4 ini. Pada dasarnya kesalahan pada kelas kontrol ini sejenis dengan kelas eksperimen. Karena siswa tidak dapat menjabarkan fakta dalam permasalahan kedalam bentuk matematika dengan baik dan benar. Selain menjabarkan kedalam bentuk matematika siswa juga harus menarik sebuah argumen berdasarkan pemikiran logis berdasarkan permasalahan yang dipaparkan pada soal nomor 4 . Sementara pada kelas kontrol ini lebih didominasi oleh jawaban yang hanya menuliskan elemenelemen yang diketahui.

Perhatikan gambar di bawah!

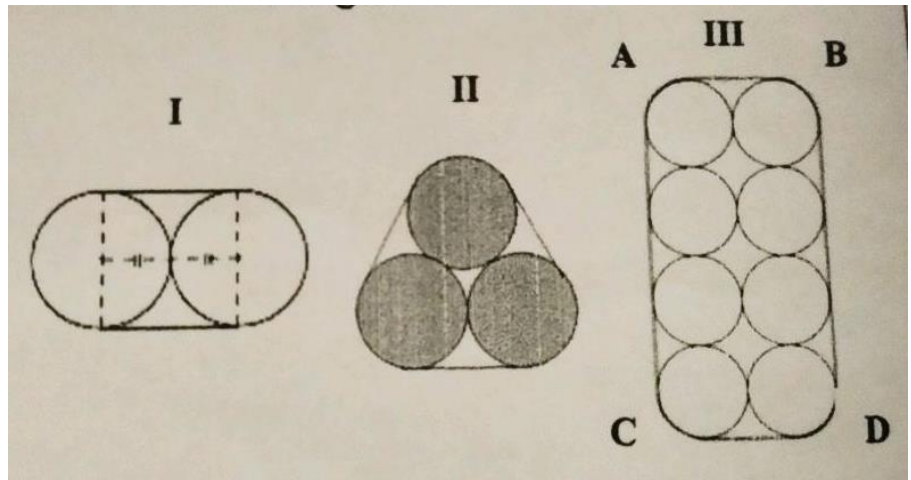

Ternyata panjang tali pada kondisi II lebih panjang dibandingkan kondisi I, namun saat diukur panjang keliling lingkaran pertama dan kedua adalah sama. Lalu apakah pada gambar kondisi III lintasan tali kurva A, B, C, D memiliki ukuran yang sama pada lingkaran kondisi I, II jika diketahui memiliki jari - jari yang sama yaitu $14 \mathrm{~cm}$ ? Jelaskan alasanmu!

Gambar 10. Soal Nomor 5 
Pada soal nomor 5 dengan indikator membangun dan menetapkan asumsi, mendapat persentase sebesar $47 \%$. Hal ini menunjukan bahwa siswa pada kelas eksperimen mengalami kesulitan dalam menyelesaikan soal nomor 5 dan berdampak tidak signifikan terhadap peningkatan kemampuan berpikir logis matematis pada indikator membangun dan menetapkan asumsi pada soal nomor 5 ini. Berikut salah satu sampel jawaban tidak tepat siswa pada soal nomor 5 dengan indikator membangun dan menetapkan asumsi.

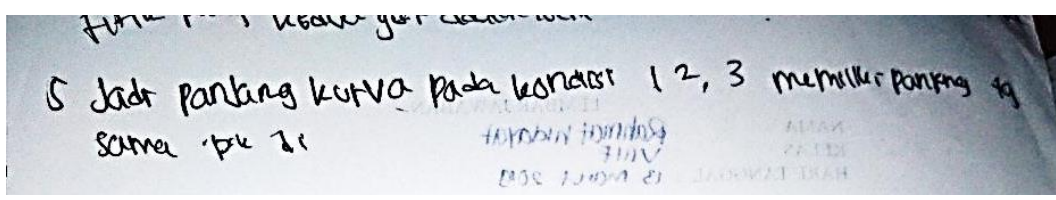

Gambar 11. Jawaban Siswa Nomor 5 Kelas Eksperimen

Pada jawaban siswa diatas jelas merupakan jawaban yang tidak tepat. Meskipun jawaban siswa itu mengarah pada jawaban yang benar, namun tidak diperkuat dengan alasan yang logis. Karena sebuah asumsi yang benar merupakan asumsi yang dibangun dengan argumen dan penjabaran yang benar dan logis. Dimana pada jawaban diatas siswa tidak menjabarkan jawaban dari awal sampai akhir, siswa hanya menjawab jawaban bagian akhir yang bisa saja berdasarkan hasil dugaan atau melihat jawaban dari teman sebangkunya.

Sedangkan untuk kelas kontrol pada soal nomor 5 dengan indikator membangun dan menetapkan asumsi, mendapat persentase sebesar $37 \%$. Hal ini menunjukan bahwa siswa pada kelas kontrol mengalami kesulitan dalam menyelesaikan soal nomor 5 dan berdampak tidak signifikan terhadap peningkatan kemampuan berpikir logis matematis pada indikator membangun dan menetapkan asumsi pada soal nomor 5 ini. Berikut salah satu sampel jawaban tidak tepat siswa pada soal nomor 5 dengan indikator membangun dan menetapkan asumsi.

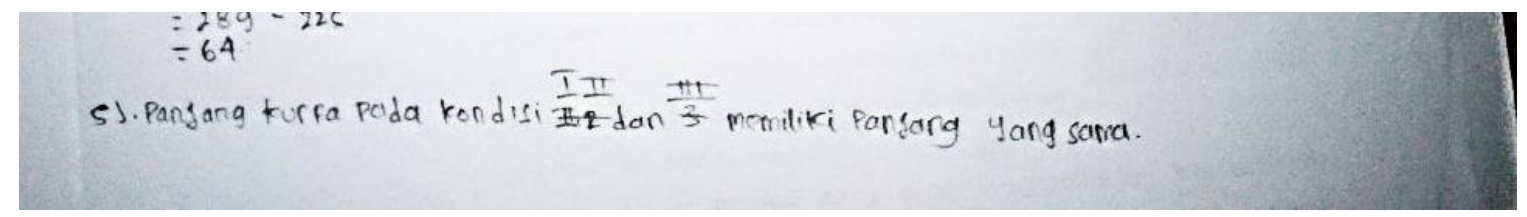

Gambar 12. Jawaban Siswa Nomor 5 Kelas Kontrol

Pada jawaban siswa diatas jelas merupakan jawaban yang tidak tepat. Meskipun jawaban siswa itu mengarah pada jawaban yang benar, namun tidak diperkuat dengan alasan yang logis. Karena sebuah asumsi yang benar merupakan asumsi yang dibangun dengan argumen dan penjabaran yang benar dan logis.

\section{KESIMPULAN}

Berdasarkan hasil maupun pembahasan diatas maka kesimpulan yang dapat ditarik adalah sebagai berikut: 
1. Secara keseluruhan kemampuan berpikir logis kelas eksperimen mendapatkan persentase sebesar 76,4\% dengan kriteria baik. Dan kelas kontrol mendapatkan persentase sebesar 56,8\% dengan kriteria cukup.

2. Pada kelas eksperimen, secara keseluruhan siswa mengalami kesulitan hanya pada soal nomor 4 . Sedangkan kelas kontrol mengalami kesulitan pada soal nomor 2, 4, dan 5.

3. Selain menemukan kesulitan siswa dalam kemampuan berpikir logis matematik, peneliti juga menemukan kesulitan siswa dalam menyelesaikan soal cerita, hal ini terlihat pada soal nomor 4 baik kelas eksperimen maupun kelas kontrol kesulitan dalam menyelesaikan soal dalam bentuk cerita.

4. Dengan analisis deskriptif kemampuan dan kesulitan siswa dalam menyelesaikan soal berpikir logis diatas dapat disimpulkan bahwa dengan penerapan aplikasi GeoGebra akan berdampak baik terhadap kemampuan berpikir logis matematik siswa SMP.

\section{DAFTAR PUSTAKA}

Arikunto, S. (2008). Prosedur Penelitian Suatu Pendekatan Praktek. Jakarta: Rineka Cipta.

Hadi, S. (2004). Metodologi Research Jilid 3. Yogyakarta: Andi.

Hidayat, W \& Sumarmo, U. (2013). Kemampuan Kemampuan Komunikasi dan Berpikir Logis Matematik Serta Kemandirian Belajar. Jurnal Matematika dan Pendidikan Matematika, 2(1), 114.

Hohenwarter, J., \& Hohenwarter, M. (2008). Introduction to GeoGebra (written for GeoGebra 3.0). Tersedia: http://docplayer.info/96840

Octaria, D. (2017). Kemampuan Berpikir Logis Mahasiswa Pendidikan Matematika Universitas PGRI Palembang Pada Mata Kuliah Geometri Analitik. Jurnal Pendidikan Matematika, 3(2), 181194.

Usdyana, D. dkk. (2009). Meningkatkan Kemampuan Berpikir Logis Siswa SMP Melalui Pembelajaran Matematika Realistik. Jurnal Pengajaran MIPA, 13(1), 1-14.

Septiati, E. (2016). Prosiding Seminar Nasional Pendidikan. Kemampuan Berpikir Logis Matematis Mahasiswa Pendidikan Matematika Pada Mata Kuliah Matematika Diskrit. Jurnal Dosen Universitas Palembang, 1(1), 394-401.

Puspitasari, I.W., Fauzan, G.A., \& Bernard, M. (2019). Penerapan PBL dengan RME Berbantuan Software Geogebra untuk Meningkatkan Kemampuan Berpikir Logis Matematik Siswa SMP. Jurnal On Education, 1(4), 679-687.

Putra, H.D. (2017). Artikel Modul Pembelajaran. Bagaimana Menganalisi Pencapaian Kemampuan Matematis Siswa?. Cimahi: IKIP Siliwangi 
Analisis Kemampuan dan Kesulitan dalam Menyelesaikan Soal Berpikir Logis Matematik Siswa SMP Dengan Penggunaan Geogebra, Gagan Aditya Fauzan, Selvia Agina, Wahyu Setiawan

Setiawan, W. (2015). Meningkatkan Kemampuan Berpikir Kritis Matematis Siswa SMP Dengan Menggunakan Model Penemuan Terbimbing. Jurnal Ilmiah UPT P2M STKIP Siwiawangi, 2(1), 91-97.

Yanti, R.N., Melati, A.S., \& Zanty, L.S. (2019). Analisis Kemampuan Pemahaman dan Kemampuan Komunikasi Matematis Siswa SMP pada Materi Relasi dan Fungsi. Jurnal Cendekia: Jurnal Pendidikan Matematika, 1(1), 209-219.

Zulfah, Z. (2017). Analisis Kesalahan Peserta Didik pada Materi Persamaan Linear Dua Variabel di Kelas VIII Mts Negeri Sungai Tonang. Jurnal Cendekia: Jurnal Pendidikan Matematika, 1(1), 12-16.

Zulfah, Z. (2019). Analisis Kemampuan Peserta Didik SMP di Bangkinang Melalui Penyelesaian Soal PISA 2015. Jurnal Cendekia: Jurnal Pendidikan Matematika, 3(2), 350-362. 